\title{
Dijital Pazarlamada Tüketici Algısı, İnternette Alışveriş Üzerine Bir Araştırma
}

\author{
Hüseyin Koçarslan ${ }^{1 *}$, Halime Kılınç ${ }^{2}$ \\ ${ }^{1}$ Selçuk Üniversitesi, İşletme Bölümü, Konya, Türkiye, (ORCID: 0000-0002-6681-538X) \\ ${ }^{1}$ Selçuk Üniversitesi, Konya, Türkiye, (ORCID: 0000-0002-8989-9870)
}

(İlk Geliş Tarihi 6 Aralık 2019 ve Kabul Tarihi 31 Aralık 2019)

(DOI: 10.31590/ejosat.659295)

ATIF/REFERENCE: Koçarslan, H. \& Kılınç, H. (2019). Dijital Pazarlamada Tüketici Algısı, İnternette Alışveriş Üzerine Bir Araştırma. Avrupa Bilim ve Teknoloji Dergisi, (17), 1263-1273.

$\ddot{O} z$

Dijital pazarlama; dijital kanalları kullanan verimli bir pazarlama yöntemidir. Bu kanallar; internet, sosyal medya ve mobil platformlardır. Burada pazarlamanın temel prensipleri geçerliliğini korumakla birlikte pazarlamada yeni anlayışlar ve yeni müşteri deneyimleri de ortaya çıkmaktadır. Bu yüzden işletmeler hem yeni müşteriler kazanmak için hem de satış yapmak için sosyal medyayı ve online alışverişi kullanmaktadırlar. Dijital pazarlamanın en önemli unsuru olan müşteriler, gerek zaman, gerek uygun fiyat ve gerekse aradıkları ürünlere ulaşma konusundaki kolaylıkları nedenleriyle dijital ortamda alış verişi tercih edebilmektedir.

$\mathrm{Bu}$ çalışma, tüketicilerin dijital pazarlama ve internette alışveriş üzerine algıları ve davranışları ölçülmeyi amaçlamaktadır. Ayrıca katılımcıların dijital pazarlama ve internette alışveriş yapma konularındaki algıları; cinsiyet, medeni durum, meslek, yaş ve aylık gelir durumu değişkenlerine göre istatistiksel olarak değerlendirilmiştir. Araştırma, Konya ilinde yaşayan farklı meslek gruplarına mensup toplam 167 kişi üzerinde yapılan anket çalışması ile gerçekleştirilmiştir.

Araştırmadan sonuçlarına göre, katılımcıların \%91,6'sının internetten alışveriş yaptığı; internetten alışverişs sıklığı en çok \%38,9 ile yılda 1-2 kez olduğu; internetten alışverişe ilk tercih nedenleri \%59,3 oranla internette satışa sunulan ürünlerin indirimli ve düşük fiyatlı buldukları için olduğu; internetten alışverişe \%55,7'lik oranla ilk sırada giyim eşyası ve aksesuar olduğu saptanmıştır. Katılımcıların online alışverişi faktörleri arasında en çok hizmet kalitesi, sistem kalitesi ve güven boyutlarına en az öznel form ile kullanım kolaylığı ve tutum boyutlarına katıldıkları saptanmıştır.

Anahtar Kelimeler: Dijital pazarlama, Tüketici algıları ve davranışları

\section{Consumer Perception in Digital Marketing, A Research On Shopping on the}

\section{Internet}

\begin{abstract}
Digital marketing; Using digital channels is an efficient marketing method. These channels are; internet, social media and mobile platforms. While the basic principles of marketing are still valid and applied, new insights and new customer experiences emerge in marketing. Therefore, businesses use social media and online shopping to gain both new customers and sales. Customers, who are the most important elements of digital marketing, can choose to exchange digitally in terms of time, price, and convenience to reach the products they are looking for.

This study aims to measure the perceptions and behaviors of consumers on digital marketing and internet shopping. In addition, participants' perceptions about digital marketing and online shopping; gender, marital status, occupation, age and monthly income status were evaluated statistically. The study was carried out with a survey conducted on 167 people from different occupational groups living in the province of Konya.

According to the results of the survey, $91.6 \%$ of the participants were shopping online; The frequency of shopping from the internet is 1-2 times a year with a maximum of $38.9 \%$; the first choice of online shopping for $59.3 \%$ compared to the products offered for sale on
\end{abstract}

* Sorumlu Yazar: Selçuk Üniversitesi, İşletme Bölümü, Konya, Türkiye, ORCID: 0000-0002-6681-538X, kocarslan1@gmail.com 
the internet for discount and low-priced; $55.7 \%$ of the Internet shopping from the first place clothing and accessories were found to be the first. It was determined that the participants had the highest quality of service, system quality and confidence dimensions, and the least personal form and ease of use and attitudes.

Keywords: Digital marketing, consumer perceptions and behaviors

\section{Giriş}

Teknolojinin gelişmesi ile birlikte mobil cihazların ve internetin kullanımının artması insanların yaşam şeklini değiştirmesi gibi alışveriş alışkanlıklarını da değiştirmiş̧ir (Ryan, 2016:1660). Bu önemli ve olumlu gelişim işletmelerin dijital medya ve buna benzeyen yeni yollarla hedef müşterileri ile iletişim kurmalarına neden olmaktadır. Tüketicilerinde bu gelişmelere olumlu cevap vermesi ile dijital pazarlamanın kullanımı artmış ve bu pazarlama alanı işletmeler için önemli hale gelmiştir. İşletmelerin karşısında artık "dijital bir tüketiciler" söz konusudur. İşletmeler için bu yeni nesil tüketicilerin isteklerini, hal ve davranışlarını anlamaları önem arz etmektedir. Bunun ise zor bir işlem olduğu söylenebilir (Alan, Kabadayı ve Erişke, 2018:493).

Dijital platformlar ve dijital kanallar sayesinde işletmeler, daha büyük müşteri kitlelerine daha az maliyetler ile ulaşarak üretmiş oldukları mamulleri ve hizmetleri daha iyi tanıtmakta, satış sonrası da hizmet imkânları sunarak tüketicilerinde de hızlı ve kolay bir şekilde geri dönüşüm imkânı sağlamaktadır (Ryan, 2016:1660).

Dijital çă̆ olarak adlandırılan 21. yüzyıl, pazarlama kavramını da çok önemli etkiler yapmakta ve onu geleneksel boyutların dışına çıkarmaktadır. Bu süreçte pazarlama olgusu, hem mekânsal hem de süreç hem de yöntem olarak birçok değiş̧imi ve gelişimi yaşamaktadır. Bu çağın getirdiği bu anlayış, dijital pazarlama kavramını ortaya çıkarmıştır. Dijital pazarlama, şirketlerin ve markaların önem verdiği ve giderek artan bir şekilde yaygınlaşan bir pazarlama türü haline gelmektedir. Bunun altında yatan en önemli nedenlerden birisi, insanların dijital ürün ve teknoloji kullanımlarının yaygınlaşması ve dijital yaşamın onların zamanlarının önemli bir kısmında yer alması olarak gösterilebilir.

Dijital pazarlama; dijital kanalları kullanan verimli bir pazarlama yöntemidir. Bu kanallar; internet, sosyal medya ve mobil platformlardır. Burada pazarlamanın temel prensipleri geçerliliğini korumakta ve uygulanmakta olmakla birlikte pazarlamada yeni anlayışlar ve yeni müşteri deneyimleri de ortaya çıkmaktadır. Günümüzde dijital pazarlama müşterilerine benzersiz yaklaşımlar sunmakta ve yeni deneyimler yaşatmaktadır.

Günümüzde çoğu insan sosyal medya üyeliklerinden en az birine veya birkaç tanesine sahiptir. Ayrıca insanların sosyal medyada harcadıkları zamansa azımsanacak kadar düşük değildir. Sosyal medyanın milyonların ilgisini üzerine çeken ve onları bir arada tutan bir platform olduğu düşünüldüğünde, iş dünyasının bu durumu önemsememesi pek mümkün değildir. Bu yüzden İşletmeler gerek yeni müşteriler kazanmak için gerekse satış yapmak için sosyal medyayı ve online alışverişi kullanmaktadır. Diğer taraftan büyük ve orta düzeyde şirketler dijital pazarlamaya bütçe ayırmadığında ve bu konuyu önemsemediğinde rakiplerinin gerisinde kalacakları hakkında birçok öngörü de bulunmaktadır. Bu yüzden şirketler artık dijital ortamda kendilerini tanıtmaya ve satış potansiyellerini yükseltmeye çalışmaktadırlar.

Dijital pazarlamanın en önemli unsuru olan müssteriler, geleneksel pazarlamayı tercih etmekle birlikte günümüzde dijital pazarlamaya ilgileri oldukça artmıştır. Müşteriler; gerek zaman, gerek uygun fiyat gerekse aradıkları ürünlere ulaşma konusundaki kolaylıkları nedenleriyle dijital ortamda alış verişi tercih edebilmektedir.

Bu çalışmada tüketicilerin dijital pazarlama ve internette alışveriş üzerine algıları ve tüketici davranışları ölçülmeye çalışılmıştır. Katılımcıların dijital pazarlama ve internette alışveriş yapma konularındaki algıları; cinsiyet, medeni durum, meslek, yaş ve aylık gelir durumu değişkenlerine göre istatistiksel açıdan anlamı değerlendirilmiştir.

\section{Literatür}

"Pazarlamanın son yıllarda çok hızlı bir şekilde gelişmesine neden faktörlerin başında hiç şüphesiz teknolojide yaşanan gelişmeler gelmektedir. Özellikle üretim, bilişim, ulaşım teknolojilerinde yaşanan yenilik ve gelişmeler işletmelerin üretim ve pazarlama faaliyetlerini olumlu veya olumsuz şekilde etkileyebilmektedir"(Öztürk, 2017: 15).

Teknolojinin pazarlama sürecini iki temel noktada etkilediğini görmekteyiz. Bunlar: yeni ürünler için firsat ve yeni süreçler ortaya koymasıdır. Örneğin; bilgi teknolojisindeki gelişmeler sayesinde dünyanın değişik yerlerinde insanların uydu aracılığı ile video konferans yapmalarıı ve internet aracılığı ile karmaşık tasarımn çizimlerinin gönderilmesine imkan sağlanmaktadır. Web siteleri ise aralarında az veya çok mesafe olan işletmeler arasında karmaşık e-ticaret yapılmasına sağlamaktadır(Perreault, Cannon ve McCarthy,2013:66). Bu gelişmeler pazarlamada yeni ufuklar açarken bu değişim ve gelişimlere ayak uydurmayan işletmelere de zarar vermiştir.

“Teknolojik faktörler, işletmeyi doğrudan ve dolaylı olarak etkileyen her türlü teknolojik yeniliklerdir (Tekin,2014: 39). Teknolojide değişim, işletmelere önemli firsatlar sunarken, bazı işletmeleri, varlığını sürdürememe tehdidi ile karşı karşıya bırakmaktadır. Bilgi iletişim teknolojisinde ortaya çıkan gelişmeler, telepazarlama, internette pazarlama gibi pazarlamaya yeni ufuklar açmıştır”"(Yükselen, 2006: 75).

Günümüzde teknoloji insan hayatında birçok etki yapmakta ve onu sosyal, psikolojik, ekonomik ve kültürel anlamda etkilemektedir. Dijital teknoloji de tüketicilerin ürünler ve pazarlarla olan ilişkilerini değiştirmektedir. Yeniden programlanan sadece bilgisayarlarımız değil; müşterilerin de kendisidir. İnternet pazarlamacılığının ve sosyal medyanın tüketicilerin davranış biçiminde ve şirketlerin iş yapmasında önemli bir etkiye sahip olması ve şirketlerin yeni gerçekliğe adapte olma zorunluluğunu getirmiştir. Bu açıdan 
pazarlamacıların, bu dijital çağda yeni zorluklar ve firsatlarla karşı karşıya olduğu söylenebilir. Siber tüketici, değişen ihtiyaçlarını karşılamak için yeni pazarlama yaklaşımlarına olan ihtiyacı açıkça göstermektedir (Wind ve Mahajan, 2002, s.44; Yasmin vd., 2015, s.69; Todor, 2016, s.51).

Küreselleşme neticesinde hedef pazarların genişlemesi ile birlikte günümüzde ise mamul ve hizmetlerin artık internet kullanımı sayesinde sosyal medyadan satılabildiğine şahitlik etmekteyiz. Yukarıda da değinildiği gibi bu durumun işletmeler için hem avantaj hem de dezavantaj oluşturduğu söylenebilir. Diğer taraftan web siteleri ve bloglar tarafindan işletme, ürünleri ve hizmetleri için yapılan yorumlar ve tepkiler karşısında işletmeler kendilerine yeni bir yol haritası seçmek durumunda kalmaktadır. Tüketicilerin işletmelerin, ürettiği mallar ve hizmetlerle ilgili yaptığı yorumlar hakkında bilgi sahibi olmak işletmelere büyük faydalar sağlamaktadır. Ayrıca tüketicilerin sosyal medyada işletme ve ürünleri ile ilgili yaptığı yorumlar diğer tüketicileri de olumlu veya olumsuz etkileyebilmektedir. (Hacıhasanoğlu, 2017:1).

Siber tüketiciler, satın aldıkları ürün ve hizmetlerden, aradıkları bilgilere, ödemek istedikleri fiyata kadar her şeyi özelleştirmeyi beklemektedir. Tüketiciler artık ürünleri istenen herhangi bir nitelik, fiyat, besin değeri, işlevsellik veya fiyat değeri gibi özelliklerin birleşimine göre sıralayabilmekte ve diğer kullanıcıların deneyimini kullanmak da dahil olmak üzere üçüncü taraf onaylarını ve değerlendirmelerini kolayca ulaşabilmektedirler. Artık dijital teknolojiyle güçlendirilmiş müşterileri kandırmak hiç te kolay değildir. Artık müşteriler marka seçerken eşdüzey kişilerin tavsiyeleri doğrultusunda sosyal çevrelerini bir kale gibi kullanarak markaların yanlış iddia ve kampanyalarından kendilerini korumaktadırlar (Wind ve Mahajan, 2002, s.44; Kotler vd., 2017, s.29). Ayrıca, bilimsel literatür, açıkça tanımlanamamış olmakla birlikte sektörde dijital pazarlama becerilerinde önemli boşluklar olduğunu öne sürmektedir (Royle ve Laing, 2014, s.65).

Dijital devrim, tüketicilere daha fazla fiyat şeffaflığı ve çoğu zaman fiyatı dikte etme şansı sunması nedeniyle pazarlamanın özüne sarsmıştır. Fiyatlandırma, müşterilerin kendi fiyatlarını (priceline.com'da olduğu gibi) önerdikleri bir dünyada veya alıcılar ve satıcıların açık artırmalarda bağımsız olarak pazarlık ettiği (e-Bay'de olduğu gibi) platformlarda, pazarlama artık yeni bir anlayışı ortaya koymaktadır. Dijital pazarlama, 'siber tüketicilerin', siber iş dünyası dünyasının ve giderek daha karmaşık, dinamik ve küresel hale gelen pazarların değişen gerçekliğini ortaya koymaktadır (Wind ve Mahajan, 2002, s.43). Ayrıca, çevrimiçi hizmetler ve World Wide Web (www) ile etkileşimli medyanın hızlı gelişimi, tüketici pazarlamacılarının çoğunu şaşırtmıştır. Birçoğu, internet etkileşimli medyanın tüketici pazarlaması üzerindeki muhtemel etkisini “tahmin etmek” için, ne yapmaları gerektiğini ve bunu nasıl yapmaları gerektiğini merak etmektedirler (Parsons vd., 1998, s.31).

Dijital Pazarlama, dijital teknolojilerin pazarlamayı nasıl daha etkili hale getirdiğini vurgulamaktadır, çünkü bireysel dikkat, daha iyi kampanya yönetimi ve daha iyi ürün, pazarlama tasarımı ve yürütme için olanak sağlar (Urban, 2003). Dijital pazarlamanın en popüler yöntemlerinden biri olmasının nedeni, bilginin çok düşük bir maliyetle işlenebileceği internettir. İnternet dijital pazarlama endüstrisinde dalgalar oluşturmaya devam ettiğinden, etkileşimli tüketici pazarı uluslararası yatırımcılar tarafından göze çarpan en umut verici sektörlerden biri olarak gelişti (Kierzkowski vd., 1996).

Pazarlama, alıcı ile satıcı arasında değişim ilişkisini konu alan ekonomik, sosyal, psikolojik, kültürel ve uygulamalı bir bilim dalıdır (Altunışık vd., 2014, s.27). Dijital pazarlama, başta Internet üzerinden olmak üzere, aynı zamanda cep telefonları, görüntülü reklamcılık ve diğer dijital ortamlar da dahil olmak üzere, dijital teknolojileri kullanan ürün veya hizmetlerin pazarlanmasıdır (http://lexicon.ft.com/Term?term=digital-marketing, E.T. 11.03.2019). Dijital pazarlama, müşterilere ulaşmak ve müşterilere dönüştürmek ve bunları korumak amacıyla dijital teknolojiler kullanarak, hedeflenen, ölçülebilir ve etkileşimli mal veya hizmet pazarlaması için kullanılan bir terimdir. Alternatif isimleri 'çevrimiçi pazarlama', 'internet pazarlama' veya 'web pazarlamadır. Dijital pazarlamanın temel amacı, markaları tanıtmak, tercihi şekillendirmek ve çeşitli dijital pazarlama teknikleriyle satışları artırmaktır (Todor, 2016, s.52).

Çoğu uzman, dijitalliğin yalnızca pazarlama için farklı bir kanal olmadığını, pazarlamaya yeni bir yaklaşım ve yeni bir müşteri davranışı anlayışı getirdiğine inanmaktadır. Bu durum, şirketlerin mobil cihazlardaki uygulama indirme sayıları, Twitter'daki tweet'lerin, Facebook'taki beğenilerin ve benzerlerinin değerini analiz edilmesini ve ölçülmesini gerektirmektedir (http://lexicon.ft.com/Term?term=digital-marketing, E.T. 11.03.2019).

Tüketici davranışlarındaki değişiklikler, firmaların pazarlama stratejilerini etkileyen en önemli konulardandır. Dijital medyanın tüketiciler tarafından artan kullanımıyla, daha fazla şirket, hedef pazarlarına ulaşmak için dijital pazarlamayı kullanmaktadırlar(Smith,2011,s.489). Bu anlamda tüketicilerin dijital dünyayla yakın ilişkileri, şirketlerin pazarlamalarında dijital alanı dikkate almalarını gerektirmiştir. Ayrıca ikinci nesil internet tabanlı uygulamalar, firmaların yenilikçi iletişim biçimlerini uygulamalarını ve müşterileriyle birlikte içerik oluşturmalarını sağlayarak pazarlama çabalarını artırmaktadır. Dijital pazarlama etkileşimini geliştirmek için pazarlamacılar, müşterileriyle ilişkiye dayalı etkileşimlere odaklanmalıdırlar (Tiago ve Veríssimo, 2014, s.703).

Tüketicilerin dijital pazarlama ve online alışveriş konusundaki algılarını ölçmek için daha önce yapılmış birkaç araştırma bulunmaktadır. Turan (2011), çevrimiçi alışveriş tüketici davranışını belirleyen faktörler üzerine bir araştırma yaptı. Yılmaz ve Tümtürk (2015), çevrimiçi alışveriş amacını etkileyen faktörleri araştırmak için bir çalışma yaptı. Cesur ve Tayfur (2015), çevrimiçi alışveriş davranışında algılanan tüketici risklerini araştırmak için bir çalışma yaptı. Bu araştırma, tüketicilerin dijital pazarlama ve online alışveriş̧ konusundaki algıları hakkındaki bulguları ve sonuçları ile literatüre katkı sağlayacaktır.

\section{Materyal ve Metot}

\subsection{Materyal}

Bu çalışma, tanımlayıcı ve kesitsel bir araştırmadır. Araştırma, Konya ilinde yaşayan ve araştırmaya katılmaya gönüllü olan farklı meslek gruplarına mensup toplam 167 kişi üzerinde yapılan anket çalışması ile gerçekleştirilmiştir. Veriler 2019 yılı Mart ayı içerisinde toplanmıştır. Araştırma anket formu, 5'i sosyo-demografik soru olmak üzere; 10'u katılımcıların online alışveriş davranışları üzerine 
çoktan seçmeli ve 39'u tüketicilerin online alışveriş ve dijital pazarlama hakkındaki algısını ölçmeye yönelik sorulardan oluşan toplam 54 soruluk bir anket uygulanmıştır. Araştırma anket forumu, 2018 yılında Genç ve Salman tarafından tarafindan yapılan yükseklisans tez çalışmasından alınmıştır. Araştırmanın 39 soruluk ölçeği 8 faktörden oluşmakta olup, bu faktörler aşağıda verilmiştir.

1. Faktör: Kullanım kolaylı̆̆ı ve tutum,

2. Faktör: Algılanan risk,

3. Faktör: Mağaza tanıma,

4. Faktör: Sistem kalitesi ve güven,

5. Faktör: Hizmet kalitesi,

6. Faktör: Algilanan fayda,

7. Faktör: Öznel norm,

8. Faktör: Bilgi kalitesi ve işlevselliği

Online alışveriş tüketici algısı ölçeğinin geçerlilik güvenirlik katsayısı (cronbach alfa değeri) 0,922 olmak üzere yüksek güvenilirlikte olduğu saptanmıştır. Araştırma verileri SPSS paket programında değerlendirilmiştir. Veriler, t testi, Anova testi ve Ki-kare testleri ile yorumlanmıştır.

\subsection{Bulgular ve Tartışma}

Araştırma anketlerinden elde edilen bulgular aşağıda verilmiştir.

Tablo 1: Katılımcıların Sosyo-Demografik Özelliklere Göre Dă̆ılımı

\begin{tabular}{|c|c|c|c|}
\hline & & Sayı (n) & Yüzde (\%) \\
\hline \multirow[t]{2}{*}{ Cinsiyet } & Kadın & 95 & 56,9 \\
\hline & Erkek & 72 & 43,1 \\
\hline \multirow[t]{2}{*}{ Medeni durum } & Evli & 110 & 65,9 \\
\hline & Bekar & 57 & 34,1 \\
\hline \multirow[t]{5}{*}{ Meslek } & Memur & 44 & 26,3 \\
\hline & $\dot{I}\langle ̧ c ̧ i$ & 36 & 21,6 \\
\hline & Öğretmen/Akademisyen & 42 & 25,1 \\
\hline & Să̆lık Çalışanı & 29 & 17,4 \\
\hline & Ev Hanımı & 16 & 9,6 \\
\hline \multirow[t]{3}{*}{ Yaş durumu } & 18-30 arast & 55 & 32,9 \\
\hline & 31-40 arast & 73 & 43,7 \\
\hline & 41 yaş ve üzeri & 39 & 23,4 \\
\hline \multirow{5}{*}{\begin{tabular}{|ll} 
Aylik & Gelir \\
Durumu &
\end{tabular}} & $500-1.500 \mathrm{TL}$ & 17 & 10,2 \\
\hline & $1.501-2.500 T L$ & 27 & 16,2 \\
\hline & $2.501-3500 T L$ & 23 & 13,8 \\
\hline & $3.501-4.500 T L$ & 39 & 23,4 \\
\hline & 4.501 ve üzeri $T L$ & 61 & 36,5 \\
\hline \multicolumn{2}{|l|}{ Toplam } & 167 & 100,0 \\
\hline
\end{tabular}

Araştırmaya katılanların sosyo-demografik olarak incelendiğinde; katılımcıların \%56,9'unun kadın; \%65,9'unun evli, \%26,3'ünün memur; \%43,7'sinin 31-40 yaş aralığında, \%36,5'inin 4.501 TL ve üzeri gelir sahibi oldukları saptanmıştır. 
European Journal of Science and Technology

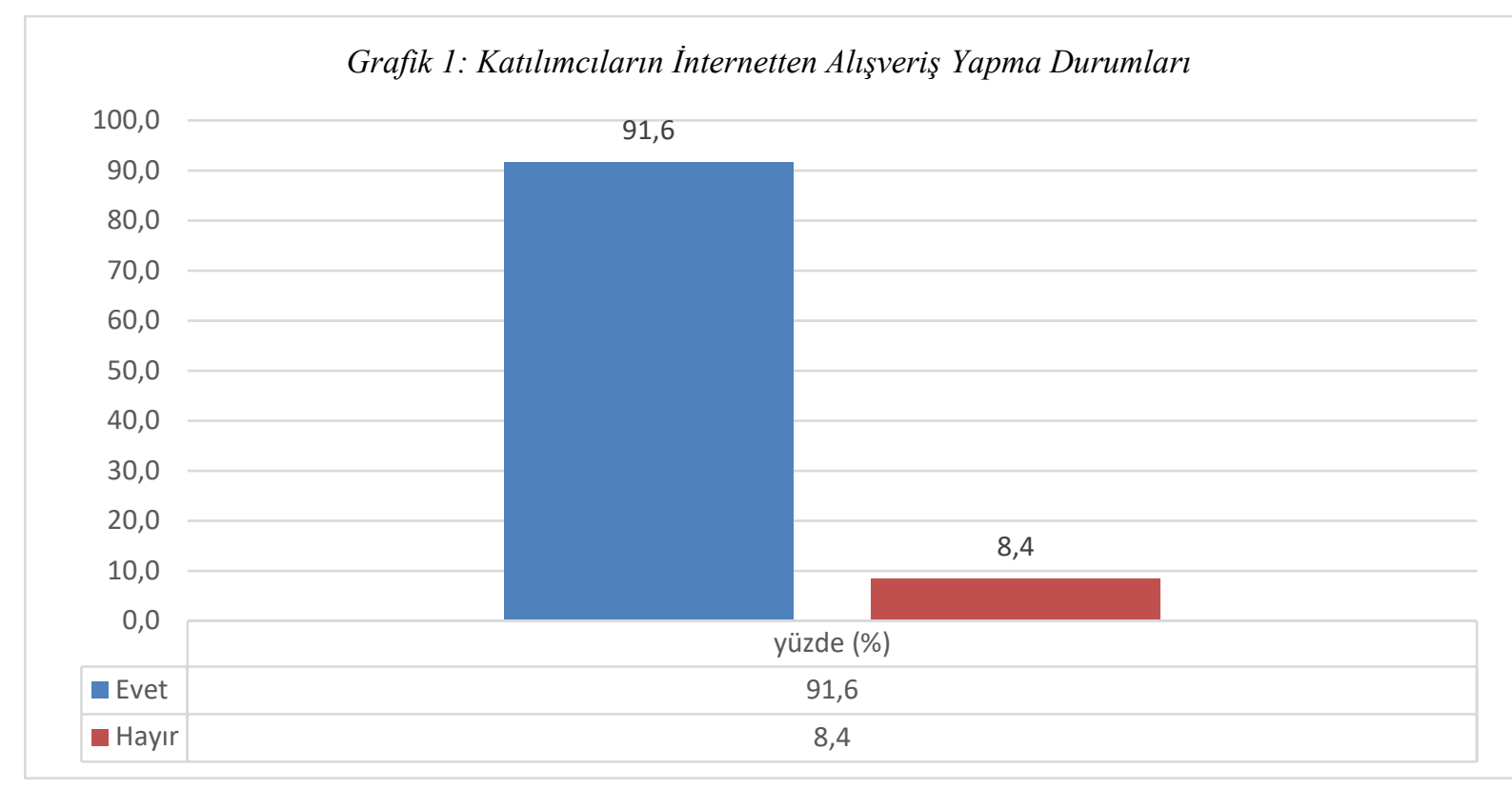

Katılımcıların \%91,6'sının internetten alışveriş yaptığı saptanmıştır.

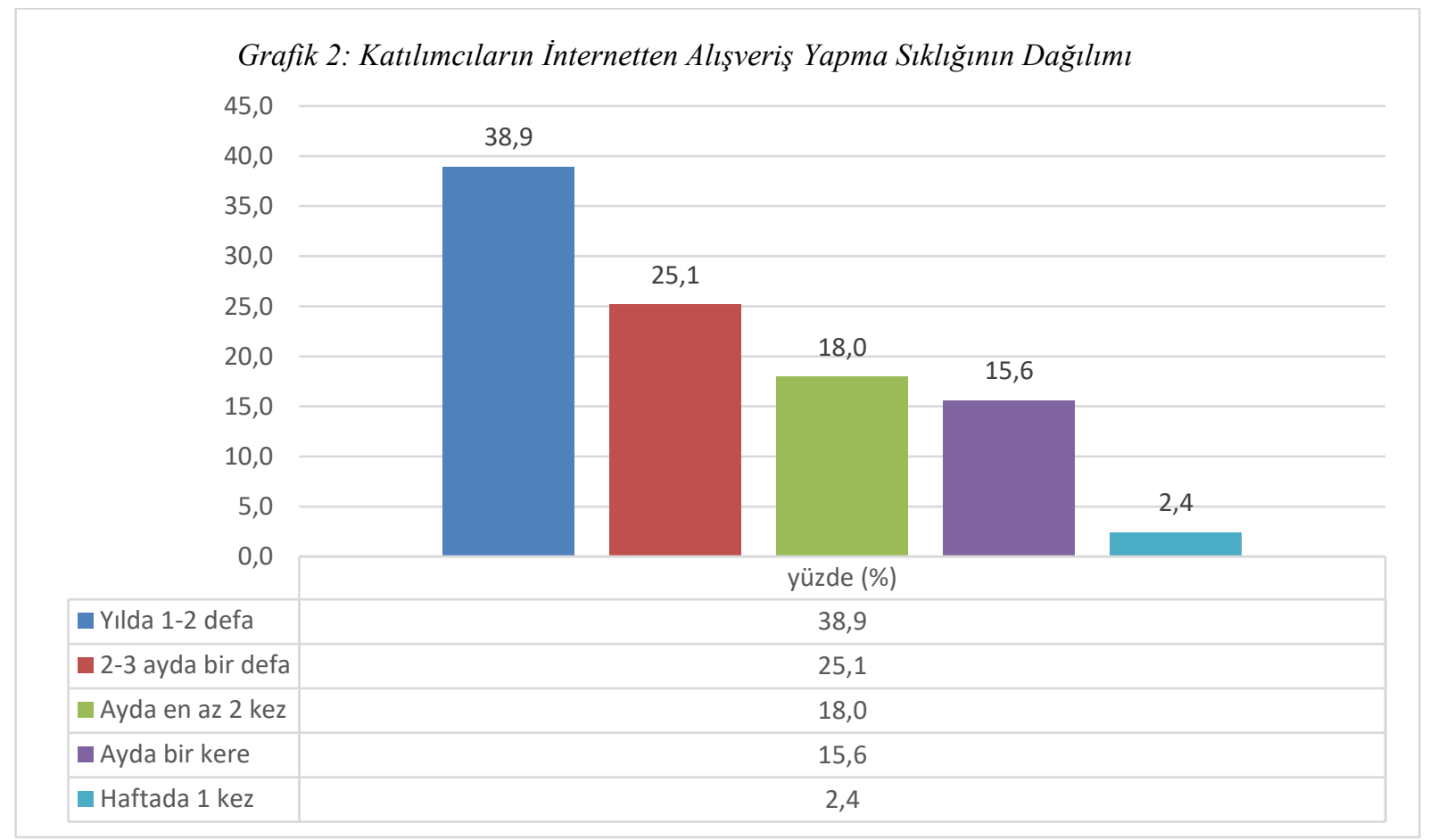

Katılımcıların internetten alışveriş sıklığ en çok \%38,9 ile yılda 1-2 kez olduğu saptanmıştır. Haftada 1 kez alışveriş yaparım diyenlerin oranı ise $\% 2,4$ 'dür. 
Grafik 3: Katılımcıların İnternetten Alışverişe Aylık Ayrıdı̆̆ı Tutara Göre Dağılımı

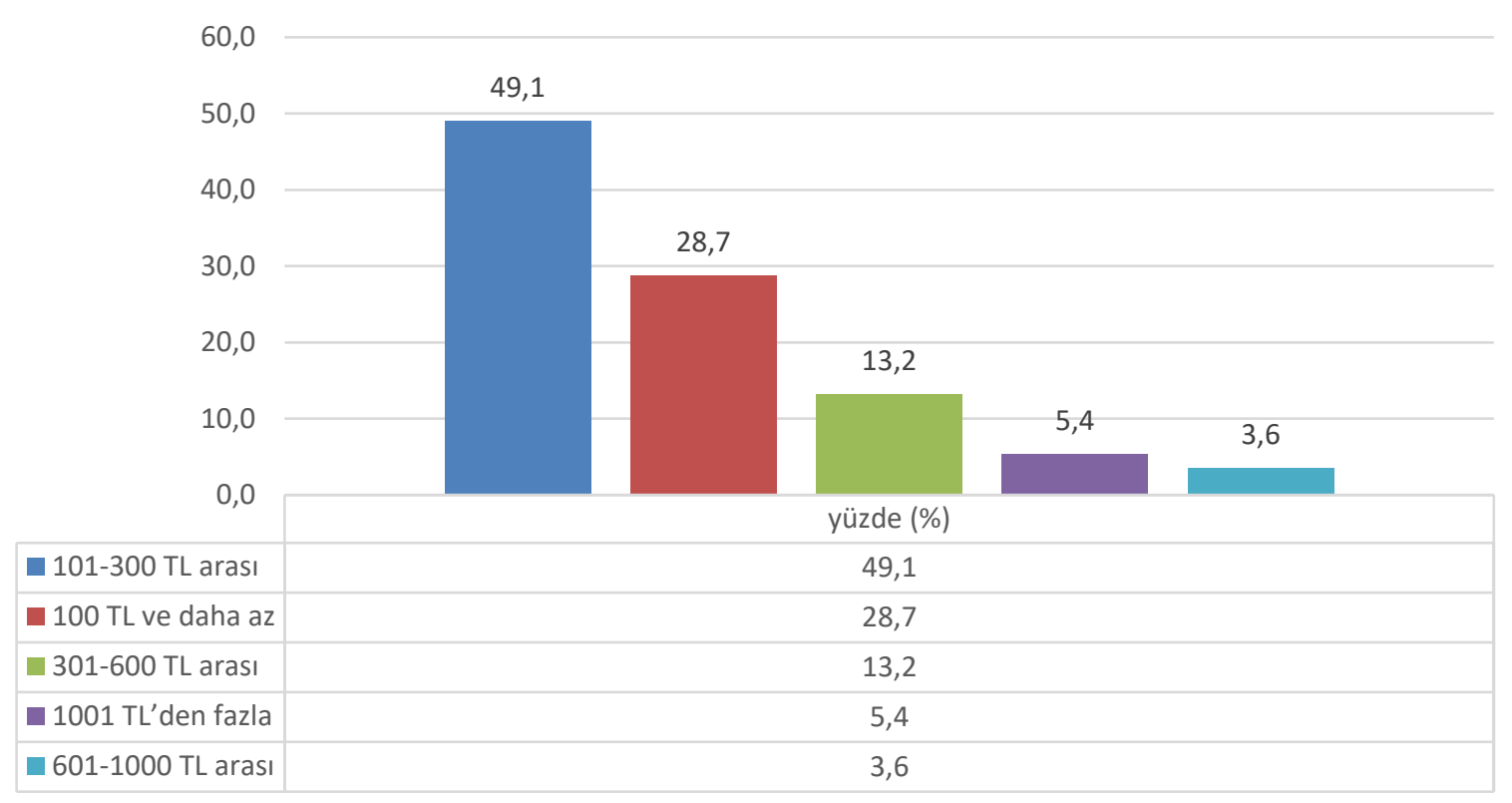

Katılımcıların internetten alışverişe ayırdığı aylık tutarın \%49,1 oranla ilk sırada 101-300 TL arası olduğu görülmektedir.

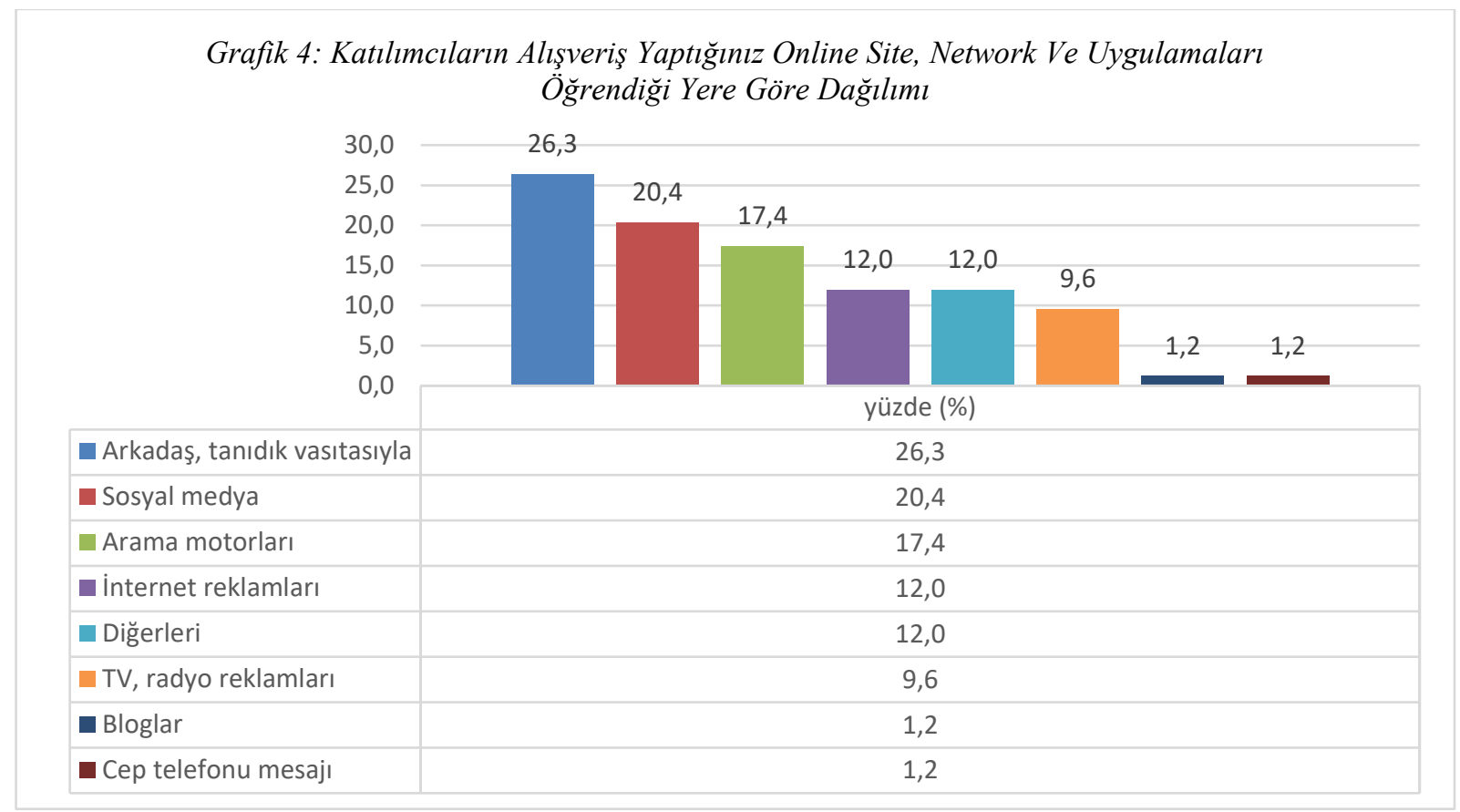

Katılımcıların internetten alışveriş için site, network ve uygulama gibi erişimleri nereden öğrendiniz sorusunda ilk sırada \%26,3 ile arkadaş ve tanıdıklar (devamında sosyal medya ve arama motorları) olarak ifade edildiği görülmüştür. 
European Journal of Science and Technology

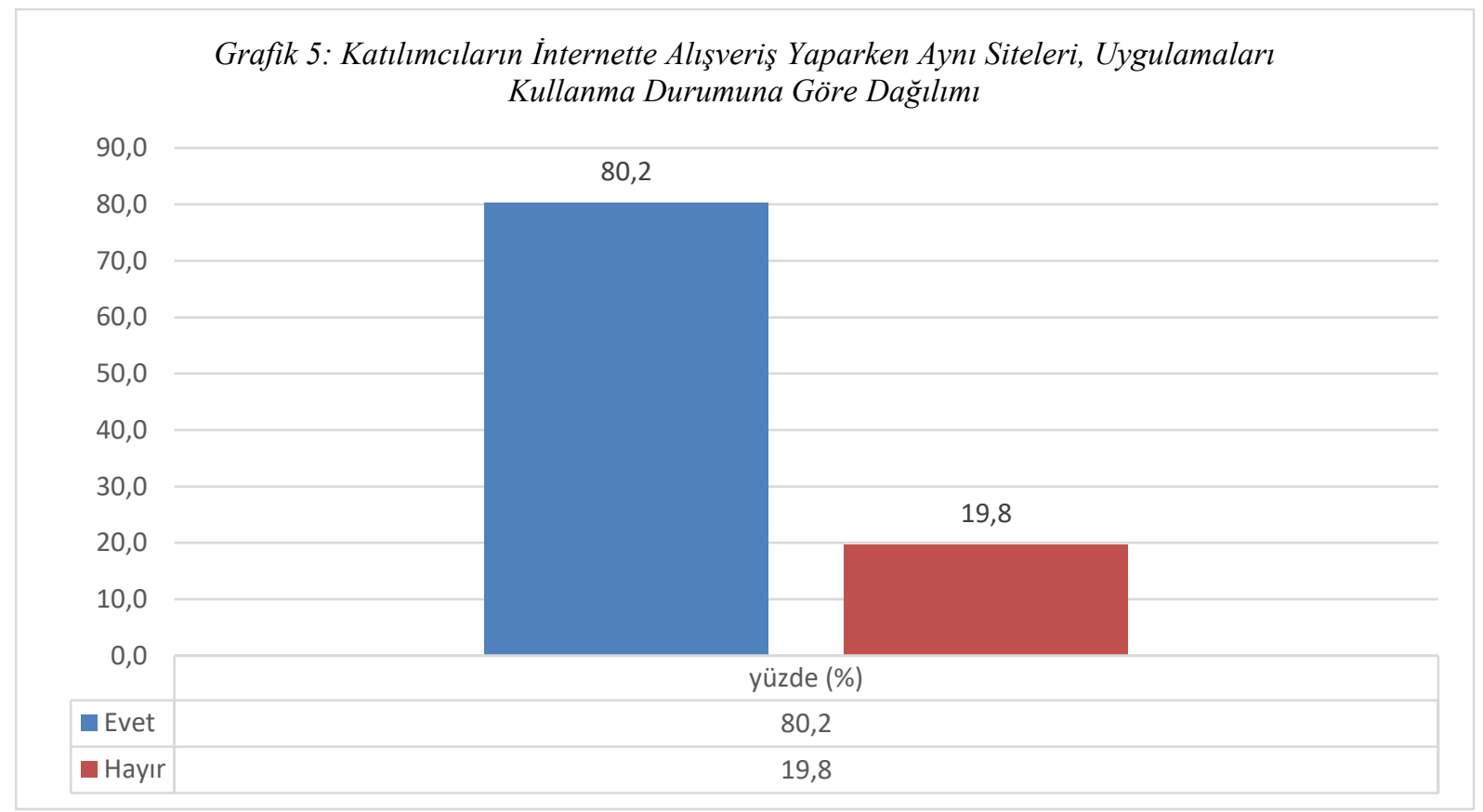

Katılımcıların \%80,2'sinin internetten alışveriş için hep aynı siteleri ve uygulamaları kullandıklarını görülmektedir.

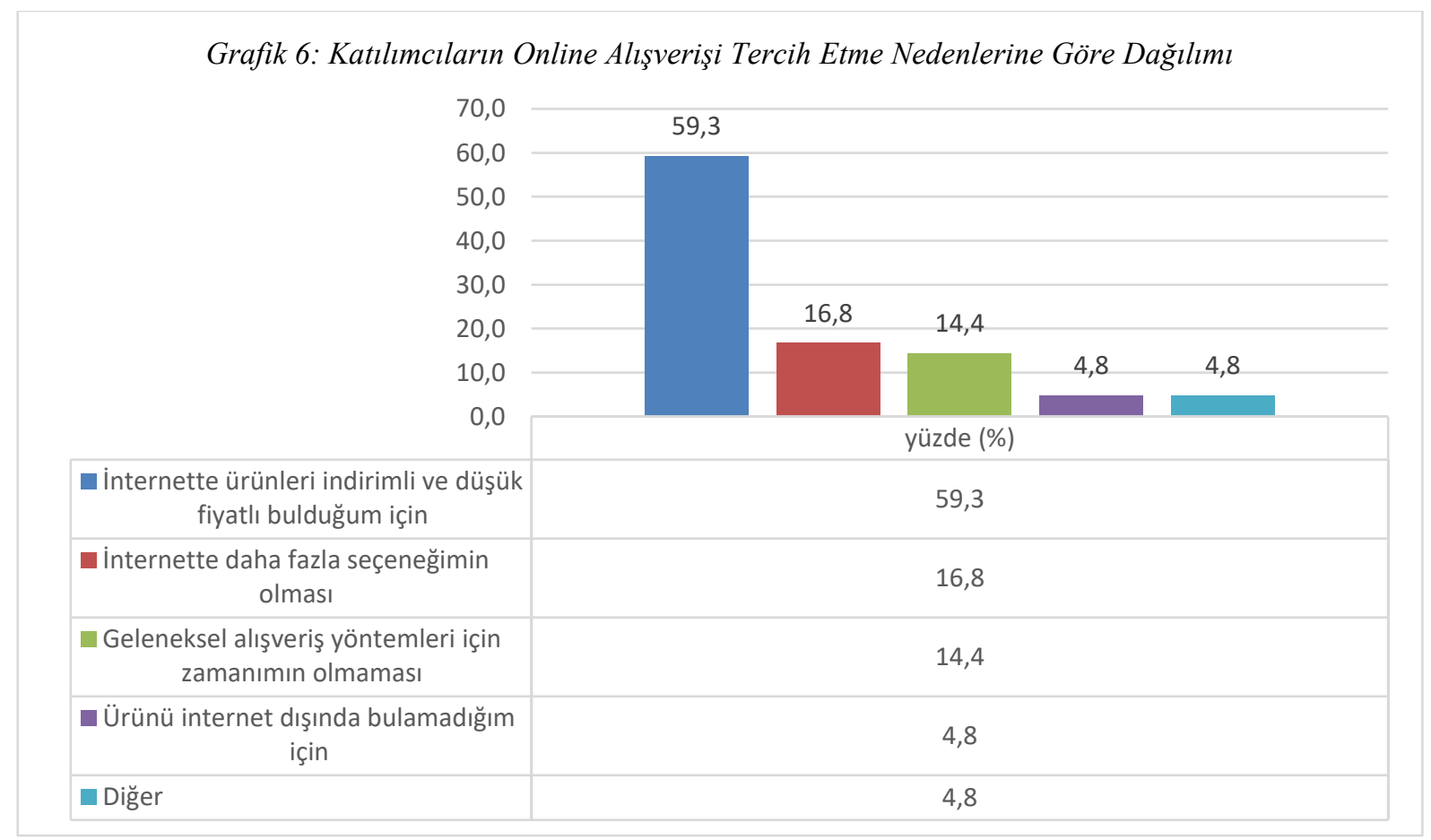

Katılımcıların internetten alışverişe ilk tercih nedenleri \%59,3 oranla internette satışa sunulan ürünlerin indirimli ve düşük fiyatlı buldukları için olduğu saptanmıştır. 
Grafik 7: Katılımcıların Online Allşverişte En çok Almayı Tercih Edilen Ürünlere Göre Dağllımı

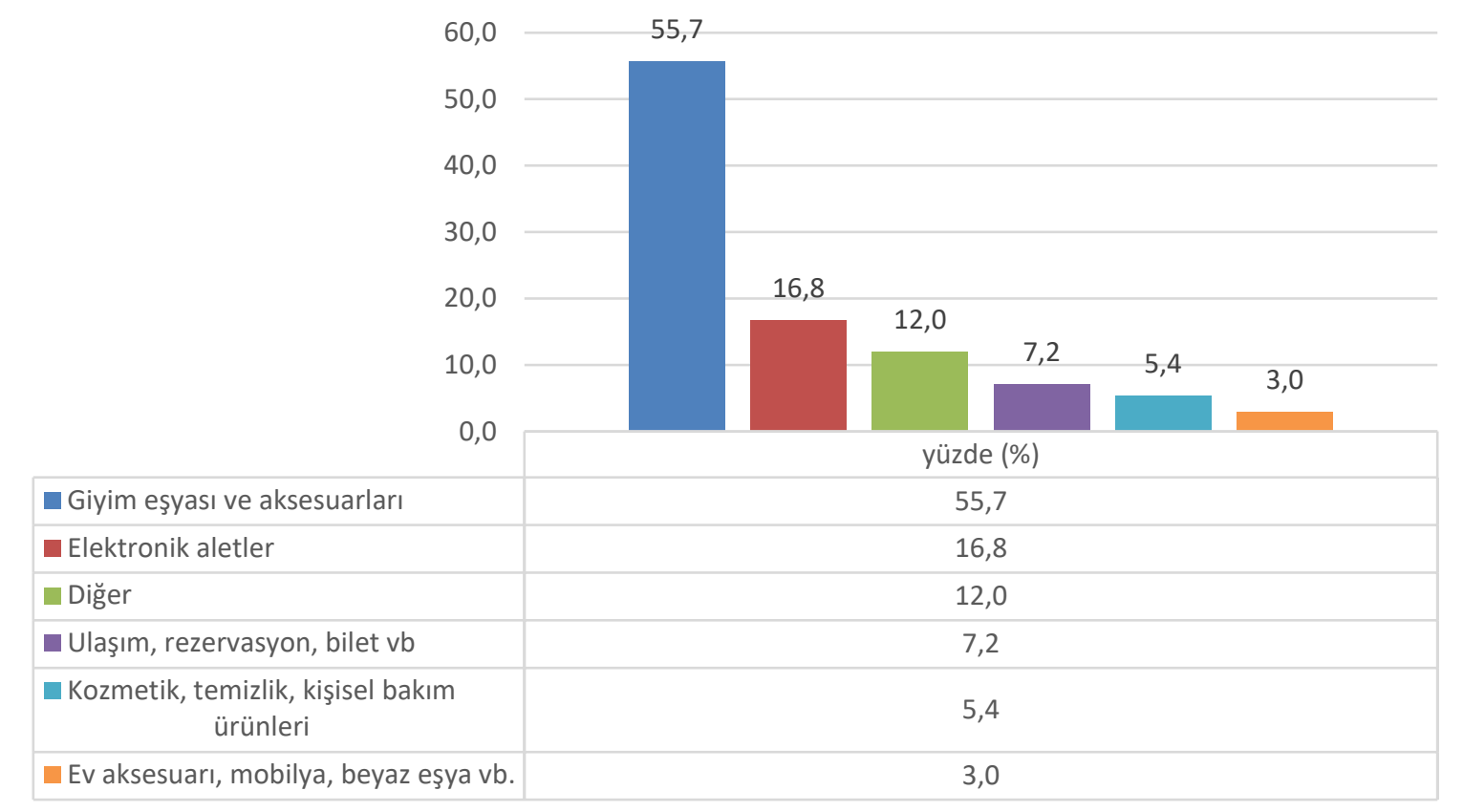

Katılımcıların internetten alışverişe \%55,7'lik oranla ilk sırada giyim eşyası ve aksesuar olduğu saptanmıştır.

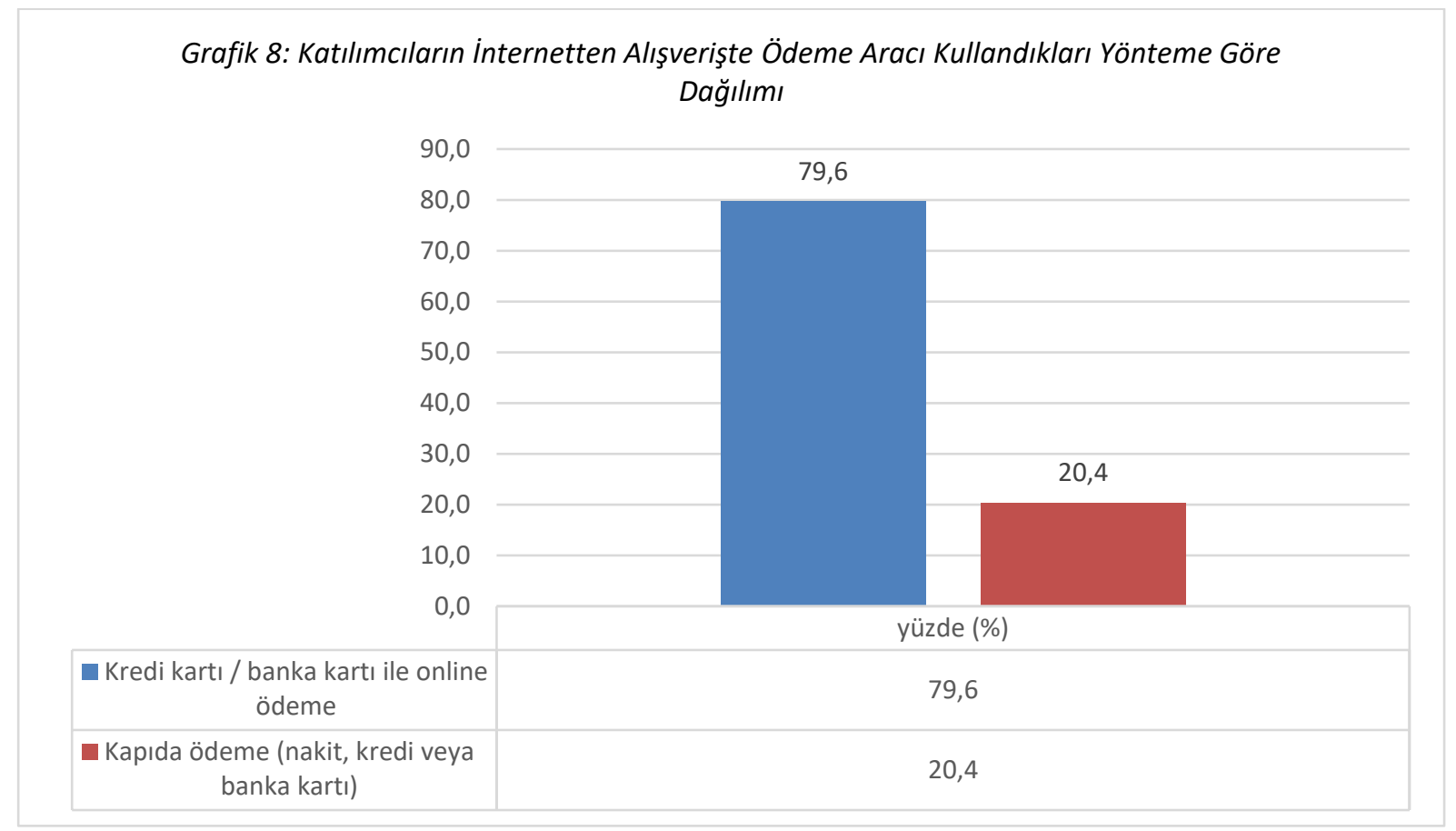

Katılımcıların internetten alışveriş ödemelerini \%79,6'lık bir oranla daha çok kredi kartı/ banka kartı ile online olarak yaptıkları saptanmıştır. 
Tablo 2: Katılımcıların Online Alışveriş Faktörleri Açısından Ortalamaların Dă̆llımı

\begin{tabular}{|l|l|l|l|l|l|}
\hline Online Alışveriş Boyutları & N & Min. & Max. & Ort. & Std. sapma \\
\hline Hizmet kalitesi & 167 & 1,00 & 5,00 & 4,0100 &, 68881 \\
\hline Sistem kalitesi ve güven & 167 & 1,00 & 5,00 & 3,9476 &, 62264 \\
\hline Mă̆aza tanıma & 167 & 1,80 & 5,00 & 3,8455 &, 54471 \\
\hline Bilgi kalitesi ve işlevselliği & 167 & 1,00 & 5,00 & 3,8024 &, 71549 \\
\hline Algılanan fayda & 167 & 1,00 & 5,00 & 3,7814 &, 71672 \\
\hline Algılanan risk & 167 & 1,00 & 5,00 & 3,5539 &, 84584 \\
\hline Kullanım kolaylı̆̆ı ve tutum & 167 & 1,25 & 5,00 & 3,4873 &, 62525 \\
\hline Öznel form & 167 & 1,00 & 5,00 & 3,2874 &, 95597 \\
\hline
\end{tabular}

Katılımcıların verdikleri cevaplar incelendiğinde; katılımcıların online alısverişi faktörleri arasında en çok hizmet kalitesi, sistem kalitesi ve güven boyutlarına en az öznel form ile kullanım kolaylığı ve tutum boyutlarına katıldıkları saptanmıştır.

\section{Sosyo-demografik değişkenlere göre katılımcıların online alışveriş faktörleri açısından değerlendirildiğinde;}

- Katılımcıların mesleklerine göre online alışveriş faktörleri açısından ortalamaların dağılımı incelendiğginde; akademisyen ve öğretmenlerin ev hanımlarına göre, online alışverişte kullanım kolaylığı ve tutum, mağaza tanıma, sistem kalitesi ve güven, algılanan fayda ile bilgi kalitesi ve işlevselliği faktörleri bakımından istatistiksel olarak anlamlı düzeyde daha çok katıldıkları saptanmıştır. Ayrıca akademisyen ve öğretmenlerin işçilere göre online alışverişte algılanan fayda boyutuna istatistiksel olarak anlamlı düzeyde daha çok katıldıkları saptanmıştır.

- Katılımcıların yaş durumlarına göre online alışveriş faktörleri açısından ortalamaların dağılımı incelendiğinde; 31-40 yaş aralığında olanların 41 yaş ve üzerinde olanlara göre online alışverişin mağaza tanıma boyutunda istatistiksel olarak anlamlı düzeyde daha çok katıldıkları saptanmıştır.

- Katılımcıların aylık gelir durumlarına göre online alışveriş faktörleri açısından ortalamaların dağılımı incelendiğinde; aylık geliri 4.501 ve üzeri TL olanların 500-1.500 TL arası olanlara göre online alışverişin mağaza tanıma boyutunda istatistiksel olarak anlamlı düzeyde daha çok katıldıkları saptanmıştır.

- Bununla birlikte, katılımcıların cinsiyet değişkenine göre ve medeni durum değişkenine göre online alışveriş faktörleri açısından istatistiksel olarak anlamlı bir farklılık saptanmamıştır.

Katılımcıların online alışveriş davranışlarının cinsiyet durumuna göre karşılaştırıldığında;

- Katılımcıların "Online alışverişi tercih etmenizdeki temel sebep nedir?" sorusuna verdikleri cevaplar incelendiğinde; kadın katılımcıların erkek katılımcılara göre daha çok "Geleneksel alışveriş yöntemleri için zamanımın olmaması" ve "Ürünü internet dışında bulamadığım için" seçeneklerine katıldıkları; erkek katılımcıların kadın katılımcılara "İnternette ürünleri indirimli ve düşük fiyatlı bulduğum için" seçeneklerine katıldıkları saptanmıştır.

- Katılımcıların "İnternetten en çok hangi ürünleri alıyorsunuz?" sorusuna verdikleri cevaplar incelendiğinde; kadın katılımcıların erkek katılımcılara göre daha çok "Giyim eşyası ve aksesuarları" ve "Kozmetik, temizlik, kişisel bakım ürünleri" seçeneklerine katıldıkları; erkek katılımcıların kadın katılımcılara "Ev aksesuarı, mobilya, beyaz eşya vb.", "Elektronik aletler" ve "Ulaşım, rezervasyon, bilet vb" seçeneklerine katıldıkları saptanmıştır.

- Katılımcıların "İnternetten alışverişte ödeme aracı olarak hangisini daha çok tercih ediyorsunuz?" sorusuna verdikleri cevaplar incelendiğinde; kadın katılımcıların erkek katılımcılara göre daha çok "Kapıda ödeme (nakit, kredi veya banka kartı)" seçeneğine katıldıkları saptanmıştır.

\section{Araştırma Sonuçları ve Tartışma}

21. yüzyıl çağı olarak da adlandırılan dijital çağının insan hayatı ve işletmeler üzerindeki etkisi her geçen gün daha da artmaktadır. $\mathrm{Bu}$ süreçte pazarlama olgusu, hem mekânsal hem de süreç hem de yöntem olarak birçok değişimi ve gelişimi yaşamaktadır. Bu çağın getirdiği bu anlayış, dijital pazarlama kavramını ortaya çıkarmıştır. Dijital pazarlama, artık şirketlerin ve markaların önem verdiği ve giderek artan bir şekilde yaygınlaşan bir pazarlama türü haline gelmektedir. Bunun altında yatan nedenlerden en önemlilerinden birisi, insanların dijital ürün ve teknoloji kullanımlarının yaygınlaşması ve dijital yaşamın onların zamanlarının önemli bir kısmında yer alması olarak gösterilebilir.

Dijital pazarlama, müşterilere ulaşmak ve müşterilere dönüştürmek ve bunları korumak amacıyla dijital teknolojiler kullanarak, hedeflenen, ölçülebilir ve etkileşimli mal veya hizmet pazarlaması için kullanılan bir terimdir. Dijital pazarlama; dijital kanalları kullanan verimli bir pazarlama yöntemidir. Bu kanallar; internet, sosyal medya ve mobil platformlardır. Burada pazarlamanın temel prensipleri geçerliliğini korumakta ve uygulanmakta olmakla birlikte pazarlamada yeni anlayışlar ve yeni müşteri deneyimleri de ortaya çıkmaktadır. Günümüzde dijital pazarlama müşterilerine benzersiz yaklaşımlar sunmakta ve yeni deneyimler yaşatmaktadır. 
Dijital pazarlamanın en önemli unsuru olan müşteriler, geleneksel pazarlamayı tercih etmekle birlikte günümüzde dijital pazarlamaya ilgileri oldukça artmıştır. Müşteriler; gerek zaman, gerek uygun fiyat gerekse aradıkları ürünlere ulaşma konusundaki kolaylıkları nedenleriyle dijital ortamda alış verişi tercih edebilmektedir.

Bu çalışmada tüketicilerin dijital pazarlama ve internette alışveriş üzerine algıları ve tüketici davranışları ölçülmeye çalış1lmıştır. Katılımcıların dijital pazarlama ve internette alışveriş yapma konularındaki algıları; cinsiyet, medeni durum, meslek, yaş ve aylık gelir durumu değişkenlerine göre istatistiksel açıdan anlamı değerlendirilmiştir.

Araştırmadan sonuçlarına göre, katılımcıların \%91,6'sının internetten alışveriş yaptığı; internetten alışveriş sıklı̆̆ en çok \%38,9 ile y1lda 1-2 kez olduğu; internetten alışverişe ilk tercih nedenleri \%59,3 oranla internette satışa sunulan ürünlerin indirimli ve düşük fiyatlı buldukları için olduğu; internetten alışverişe \%55,7'lik oranla ilk sırada giyim eşyası ve aksesuar olduğu saptanmıştır. Katılımcıların online alışverişi faktörleri arasında en çok hizmet kalitesi, sistem kalitesi ve güven boyutlarına en az öznel form ile kullanım kolaylığı ve tutum boyutlarına katıldıkları saptanmıştır.

\section{Kaynakça}

Alan, A. K., Kabadayı E. T. \& Erişke, T. (2018). İletişimin Yeni Yüzü: Dijital Pazarlama Ve Sosyal Medya Pazarlamasi, Electronic Journal of Social Sciences, 17(66).

Altunışık, R., Özdemir, Ş., ve Torlak, Ö. (2014). Pazarlama ilkeleri ve yönetimi. Beta yayınevi. İstanbul,

Hacıhasanoğlu, B.(2017). Sosyal Medyada Pazarlama Stratejilerinin Oluşturulması Ve Telekomünikasyon Sektörüne İlişkin Bir Uygulama, Yüksek Lisans Tezi, İstanbul ticaret Üniversitesi, İstanbul,

Kierzkowski, A., McQuade, S., Waitman, R., \& Zeisser, M. (1996). Current research: marketing to the digital consumer. The mckinsey quarterly, (2), 180-183.

Kotler, P., Kartajaya, H., \& Setiawan, I. (2017). Marketing 4.0: do tradicional ao digital. Sextante.

Parsons, A., Zeisser, M., \& Waitman, R. (1998). Organizing today for the digital marketing of tomorrow. Journal of Interactive Marketing, 12(1), 31-46.

Perreault, W., Cannon, J.,McCarthy, J. (2013). Pazarlamanın Temelleri, Nobel Yayınları, 13.Baskı, Ankara

Ryan, D. (2016). Understanding digital marketing: marketing strategies for engaging the digital generation. Kogan Page Publishers.

Royle, J., \& Laing, A. (2014). The digital marketing skills gap: Developing a Digital Marketer Model for the communication industries. International Journal of Information Management, 34(2), 65-73.

Smith, K. T. (2011). Digital marketing strategies that Millennials find appealing, motivating, or just annoying. Journal of Strategic Marketing, 19(6), 489-499.

Tekin, V.N.(2014). Pazarlama İlkeleri: Politikalar Stratejiler Taktikler. 3 baskı, Ankara: Seçkin Yayıncılık,

Tiago, M. T. P. M. B. \& Veríssimo, J. M. C. (2014). Digital marketing and social media: Why bother?. Business horizons, 57(6), 703708.

Todor, R. D. (2016). Blending traditional and digital marketing. Bulletin of the Transilvania University of Brasov. Economic Sciences. Series V, 9(1), 51.

Urban, G. (2003). Digital marketing strategy: text and cases. Prentice-Hall, Inc..

Öztürk, A. (2017). Pazarlama İlkeleri, Gazi Kitabevi Yayınları, 3. Baskı, Ankara,

Wind, J., \& Mahajan, V. (2002). Digital marketing. Symphonya. Emerging Issues in Management, (1), 43-54.

Yasmin, A., Tasneem, S., \& Fatema, K. (2015). Effectiveness of digital marketing in the challenging age: An empirical study. International Journal of Management Science and Business Administration, 1(5), 69-80.

Yükselen, C. (2006). Pazarlama, İlkeler-Yönetim, Detay Yayınc1lık, Ankara, 5.Bask1,

http://lexicon.ft.com/Term?term=digital-marketing, E.T. 11.03.2019. 